\title{
樹脂冷凍割断法によるウサギ脊髄の走查電顕的研究
}

\author{
山陰労災病院整形外科 \\ 大 月 健 二

\section{Scanning Electron Microscopic Studies of Rabbits Spinal Cord by Resin Cracking Method}

By

\author{
Kenji Ohtsuki \\ Sanin Rosai Hospital
}

\begin{abstract}
The availability of the scanning electron microscope in revealing fine details of the Surface morphology of cells and tissues has been already established. Recently, scanning electron microscopic studies of nervous tissue have been reported on the chick spinal cord, cilia in the brain, isolated nerve fibers.
\end{abstract}

However, all of these studies have treated with the surface morphology of cells and tissues, and there have been no studies performed on the inner structure, as far as is know.

In the present study on the anterior horn cells, the neuroglia cells and the mylinated nerve fibers of the spinal cord as observed with the scanning electron microscope, the author attempted not only to reveal the surface morphology of cells and tissues but also their interior structure, making use of Tanaka's freezed resin cracking method.

Small cubes cut from the spinal cord of the rabbit were fixed and dehydrated, and embedded in gelatin capsules filled with Cemedine 1500. The Cemedine was hardened at$30^{\circ} \mathrm{C}$ and the capsules were cracked in two pieces. The cracked surface of the specimen was observed under the scanning electron microscope with following results:

1. In the cytoplasm of the anterior horn cell the Nissl bodies were observed like specks. The Nissl bodies were denser than the cytoplasm surrounding them and contained numerous granules (about $400 \dot{A}$ in diameter) and membranous structures oriented parallel to each other. In the cytoplasm corresponding to the Golgi regions many vesicles and cisternal and membranous structures could be seen. On the surface of nerve cell bodies small swollen terminations of axons, which seemed to be end-bulbs, were observed.

2. The membranes consisting of myelin sheaths, which surrounded the axon as a whirlpool, were observed in three dimensions. The myelin sheath sometimes emerged thinner processes which could be considered to be the cytoplasmic processes of the neurogia cell.

3. The cilia covering the ependymal cells of the central canal were fairly uniform in number (12-15) from cell to cell, and were arranged in a tuft for each cell. The surface was also rich in microvilli which formed various shapes.

細胞組織の表面微細構造の研究には, 走查電子顕微 鏡が非常に有効であるということは, すでに多くの研 究によって証明されている，そのうち，神経組織の走 査電顕による研究としては, 鷄胎の脊䯣 (Boyde et al., 1968) 脳室の 線毛 (Dalen, 1971) 運動神経細胞 (Hamberger et al., 1970) 末梢神経線維 (Speu cer et al., 1971) 等がある, しかしてれらの研究はすべ て細胞組織の表面構造についてであって, 内部構造を 追求したものはない.

著者は細胞組織の表面構造だけでなく，その内部構 造をむ研究対象として, 田中の 樹脂冷凍割断法を用 い, 脊䯣の前角細胞, 神経膠細胞, および有䯣神経線 
維の観察を行ない，若干の知見を得たので報告する.

\section{材料および方法}

材料 ウサギ 体重 $2.5 \sim 3.5 \mathrm{~kg}$

方法 エーテル麻酔下で腹部大動脉より $2.5 \%$ グル タールアルデヒドリン酸綵衝液 (pH 7.4) で灌流, 10 分後脊髅をとり出し, これを $7 \mathrm{~mm} \times 2 \mathrm{~mm} \times 2 \mathrm{~mm}$ の組織片とする．との組織片を $5 \%$ グルタールアルデ ヒドリン酸緩衝液 ( $\mathrm{pH} \mathrm{7.4)} \mathrm{で} 2$ 時間固定し，さら に $1 \%$ 四酸化オスミウム酸で 3 時間, $4{ }^{\circ} \mathrm{C}$ で後固定, 上昇エタノール系列で脱水後, 15 分間プロピレンオ キキサイドにひたし，樹脂冷凍割断法 (Tanaka, 1972) を行なった. すなわち，セメダイン 1500 をい れた 2 号カプセル中に試料を包埋して，乙れを一 $30^{\circ} \mathrm{C}$ のクリオスタット内で涷結させ，のみと槌で 割断す る, 割断後試料についているセメダイン 1500 をプロ ピレンオキサイドで除去し，アミールアセテイトで 20 分間脱水, 次いで Critical drying method (Anderson, 1951) 乾燥させる. 試料の割面に, カーボン と金で二重蒸着をおこない，HITACHI，HSMー2 型 走查電子顕微鏡で観察した。

\section{所見および考察}

脊䯣運動神経細胞は Niss1 小体の豊富な存在が特 徵的である. 神経細胞の透過電顕像において Niss1 小 体の像に対応するものは, 粗面小胞体および自由リボ ゾームの 集合体である. このととは Palay および Palade (1955) によって明らかにされている。 また Bodian (1964) によれば春喣前角細胞は細胞体がき わめて大きく, 特徽的な細胞質および核, それにミナ プスを有するゆえに容易に識別されるといっている. すなわち, 細胞質にはリボゾームの付着した小胞体の 集団が多数散存し, 小胞体の間淂には自由リボゾーム が無数にみられ，通常てれらはロゼットを形成してい る. そしてその間の比較的電子密度の低い部分に, 多 くのミトコンドリア, 神経細線維, Golgi 体が存在す る.

著者の走査電顕観察によれば, Niss1 小体に相当す る部分は周囲の細胞質にくらべて緻密で, 中には多く の顆粒状体が含まれている (図 I ). この顆粒状体は 直径 500 A でリボゾームに関係するすの之考えられ る. (TANAKA, 1972) また Nissl 小体の中には線 状体も見られる.これらは透過電顕像でみられる粗面

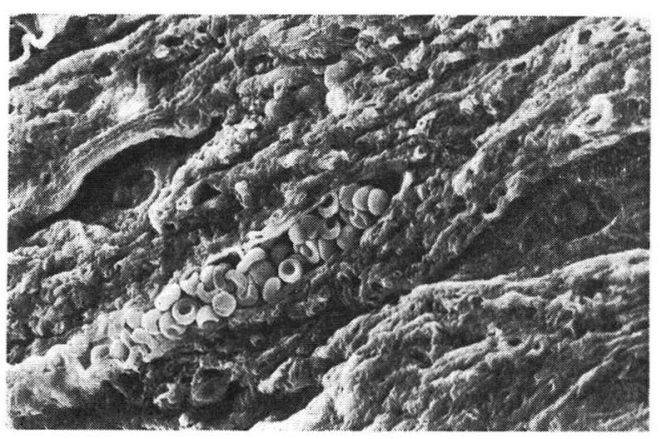

図 1

小胞体に相当するすのであろう. Niss1 小体周囲の粗 な部位，特に核の近くの部には多数の直径 $1000 \dot{\mathrm{A}}$ の 小胞扔よび㑇平円筒状の膜構造物が存在する. これら は透過電顕像で細胞体に散存性にみられる, Golgi 体 であると考えられる. ミトコンドリアは Niss1 小体 間の細胞質に普扁的に存在している. 透過電顕で観察 される，内外 2 枚のミトコンドリア膜は不明である が, ミトコンドリア櫛は観察される. 一方その他の細 胞内小器管である神経細線維, 神経細管等の同定はで きなかった。

次に神経線維についてみると, 有骾神経線維の断面 は透過電顕像によると, 軸索をとりまく明暗交互の層 板構造の重積からなり, 軸索内には多数の神経細管, 神経細線維およびミトコンドリヤが見られる. 走查電 顕による断面像では, ミエリン鞘が軸索を渦巻状にと りまいている膜からできていることが立体的に観察さ れる. 一般にてれらは波状を呈しているが，乙れは乾 燥時の人工産物と考えられる. 軸索はスポンジ状を呈 し，時にミトコンドリヤと思われる物体がみられた (図 II). ミエリン鞘の表面を観察すると，その最外層 には微細なコラーゲン線維と思われる線維状体が走っ

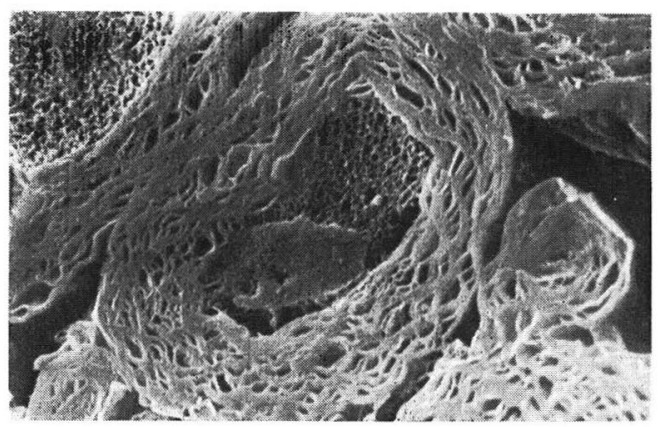

図 2 
ているのが見られる，乙の所見は Moran (1953) の 有䯣神経線維の模式図任示されるもの之一致するもの である．また䯣鞘が枝状の突起を出している像が観察 された. Bunge (1961) によれば, 喵鞘は突起物によ って神経膠細胞と連絡しているという. 著者の観察し た枝状の分枝む軸索自体の分枝ではなく，神経膠細胞 と髄鞘の連絡の突起物であろう.

最後に神経膠細胞について述べると, 中枢神経系の なかの神経膠細胞は, 星状膠細胞, 稀突起膠細胞, 小 膠細胞, および上衣細胞の 4 種が区別されている.し かし透過電顕標本においては，その切片がうすいため 全体像をつかむとと，および他の細胞要素との関係を つかむことが困難であるため，上衣細胞をのぞいては これらの細胞種類を判別することは容易ではないとい う (Hama, 1971).

走查電顕観察であ上衣細胞以外の神経膠細胞の正確 な同定は不可能であった. しかし, 神経細胞に近接し て随伴細胞の型で存在し, 周辺に有䯣神経線維をとも なう細胞は, 稀突起膠細胞と思われ，また神経細胞と 血管の間に位置し，その突起をそれぞれ神経細胞体お よび血管壁に出し奉䯣血液関門の形態と思われる像を 呈しているむのは星状膠細胞であろう. 白質にあって は, 有䯣神経線維の間に散存し, その突起を䯣鞘に送 っている細胞は稀突起細胞と考えられる. 一方上衣細 胞は脊䯣中心管の表面を被覆し単層円柱上皮様の配列 を示している. この細胞の自由表面には多数の線毛 および微䋐毛が 密生している. 上衣細胞に関しては Brightman, Palay (1963) および Kohno, Usui （1966）らによる透過型電顕による研究がある. 彼等 によれば脳室の線毛は不均等に分布し, 微綫毛ともい いがたい小さな不規則な突起物が豊富に存在すると いう。また中心管の上衣細胞に関しては, Schultz et al. (1956) のうなぎ研究がある.すなわち, その自由 表面は 2 つの型の突起を有している， 1 つは球根状の 細胞質の突起である微䋐毛と, 他の 1 つは真の線毛で ある，乙れら 2 種類の突起は同一の上衣細胞表面に存 在し, 線毛は他の動物に見られるものと形態学的にほ とんど相違ないとのべている.

著者の走查電顕観察に上れば, 上衣細胞表面に密生 する, 多数の線毛および微䄉毛は, あたかむ生きてい るように立体的像で 観察された. 乙の線毛は 10 数本 が 1 つの叢をなして 1 個の 細胞表面中心部より突出 し, 全体的にみれば, 稲の苗が田植されている様にみ

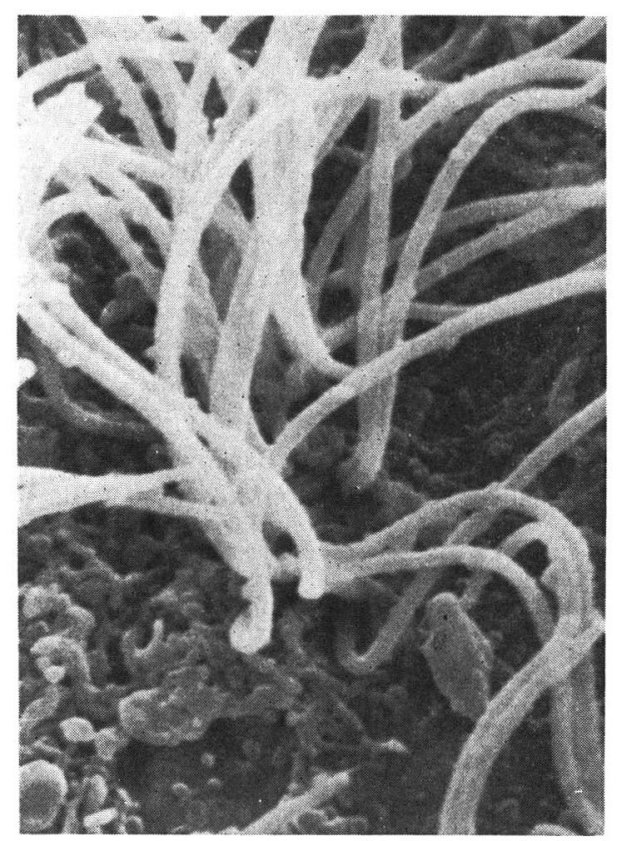

図 3

えた。一方微䋐毛は, 長さが線毛に比していちじるし く短かく種々の形態を示し，その先端は太鼓ばち状に ふくれている. これらの微䋐毛む細胞表面の中心部に 密生しており, 細胞の辺縁部には, ほとんど見られな かった(図III). 線毛の機能についていえぱ, 従来その 運動の方向が脳脊䯣液の流れ之一致しているといわ机 ている. 脳脊䯣液の流れと脳室線毛運動との関係につ いては, Dalen et al. (1971) および Wohthington et al. (1963) らの研究がある. 彼等に上れば, 線毛 運動は一定方向に調整されているようであり，乙れは 脳室における脳脊䯣液の循環に重要な役割をはたして いるという．中心管の上皮細胞も同様な運動を有する と考えられ，著者の所見でも線毛は，ある一定方向に むいて固定されていた. しかし線毛運動と中心管内の 脳脊䯑道液の流れとの相関々係については明らかな事は わからない。

\section{文献}

1) Hamberger, A., H. A. Hansson and J. Sjöstrand: Surface structure of isolated neurous. Detachment of nerve terminals during axon regineration. J. Cell Biol. 47: 319-331 (1970).

2) Kohno, K. and T. Usui : Electron micros- 
copic studies on ependymal cilia and their basal feet on the ventral stalk of the rat subfornicai organ. Bull. Tokyo Med. Dent. Univ. 13: 381-405 (1966).

3) Fernandez-Moran, H. : Sheath and axon structures in the internode portion of vertebrate myelinated nerve fibers. An electron microscope study of rat and frog sciatic nerves. Exp. Cell Res. 1 : 309-340 (1950 b).

4) Palay, S. L. and G. E. Palade: The fine strncture of neurous. J. biophys. biochem. Cytol. L : 69-88 (1955).

5) Schultz, R., E. C. Berkowitz and D. C. Pease: The electron microscopy of the lam- prey spinal cord. J. Morphol. 98: 251-273 (1956).

6) Spencer, P. S. and A. R. Lieberman: Scanning electron microscopy of isolated peripheral nerve fibers. Normal surface structure and alterations proximal to neuromas. Z. Zeliforsch. 119: 534-551 (1971).

7) Tanaka, K.: Freezed resin craking method for acanning electron microscopy of biological materials. Naturwiss. 59: 77 (1972).

8) Worthington, W.C., JR, and R.S. Cathcart, III. : Ependymal cilia : Distribution and activity in the adult human brain. Science. 139: 221-222 (1963).

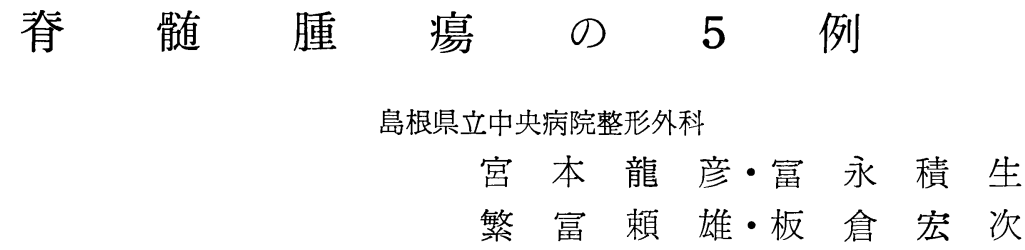

\title{
Five Cases of the Spinal Cord Tumor
}

\author{
By \\ T. Miyamoto, S. Tominaga, Y. Shigetomi \\ \& K. Itakura \\ From the department of Orthopedic Surgery, Shimane \\ Prefectural Central Hospital
}

Five cases of the spinal cord tumor which we have recently experienced were reported.

Case 1. a male, aged 42 years, was neurinoma located in the extramedullary region of the second lumbar vertebrae.

Case 2. a male, aged 64 years, was malignant meningioma located in the extradural space of the third lumbar vertebral region.

Case 3. a male, aged 41 years, was plasmacytoma located in the extradural space of the first and second thoracic vertebrae.

Case 4. a female, aged 46 years. A myelogram showed a complete block of contrast material between $\mathrm{C}_{1-2}$.

Case 5. a female, aged 44 years. A myelogram showed a defect of the contrast material on the left side at the third cervical vertebral region.

We could remove the tumor completely in the case 1 , and partially in the case 2,3 .

In the case 4, 5 we practised only laminectomy for effect of decompression.

At the postoperative course the patient's condition was relatively good in the case 1 , $3,4,5$. 